\title{
Supporting Information Biologically Active Amphotericin B-Calix[4]arene Conjugates
}

Valérie Paquet, Andreas Zumbuehl and Erick M. Carreira*

Laboratorium für Organische Chemie, ETH Hönggerberg, CH-8093 Zürich, Switzerland.

$\begin{array}{lr}\text { General information } & \text { S2 } \\ \text { Susceptibility Assay } & \text { S2 } \\ \text { Hemolytic Assay } & \text { S3 } \\ \text { Synthesis and Characterization } & \text { S3 } \\ { }^{1} \text { H NMR spectrum of } \mathbf{3} & \text { S6 } \\ { }^{1} \text { H NMR spectrum of } \mathbf{4} & \text { S7 } \\ \text { HPLC spectrum of } \mathbf{3} & \text { S8 } \\ \text { HPLC spectrum of } \mathbf{4} & \text { S9 } \\ \text { MS spectrum of } 3 & \text { S10 } \\ \text { MS spectrum of } 4 & \text { S11 }\end{array}$ 


\section{$\underline{\text { General information }}$}

All reactions were carried out in oven-dried glassware under an atmosphere of argon. Amphotericin B (AmB) was purchased from Apollo Scientifics (90\% HPLC purity). All the other compounds were purchased from Fluka, Senn and Aldrich and used without further purification. Dimethylformamide was purified by distillation and methanol was distilled over magnesium oxide. Diisopropylethylamine was distilled from $\mathrm{KOH}$ under nitrogen. The reactions were monitored by thin layer chromatography using Merck Silica Gel 60 FB254B plates and visualized using UV and aqueous ceric ammonium molybdate stain. Flash chromatography was performed using E. Merck Silica Gel 60 (230-400 mesh). The Ultra2 solution was a mixture of $\mathrm{CHCl}_{3} / \mathrm{MeOH} / \mathrm{H}_{2} \mathrm{O}$ in a ratio of 10/6/1. Gel filtration was performed using Sephadex LH-20 which was swelled at least 3 hours at room temperature in the solvent used for the separation. ${ }^{1} \mathrm{H}$ NMR spectra were recorded in DMSO$d_{6}$ on a VARIAN Mercury $300 \mathrm{MHz}$ spectrometer. Chemical shifts are reported in ppm on the $\delta$ scale from an internal standard of residual DMSO $(2.54 \mathrm{ppm})$. The data are reported as follows: $(\mathrm{s}=$ singlet, $\mathrm{d}=$ doublet, $\mathrm{t}=$ triplet, $\mathrm{q}=$ quartet, $\mathrm{m}$ $=$ multiplet or unresolved, $\mathrm{br}=$ broad signal, coupling constant in $\mathrm{Hz}$, integration). Mass spectrometric measurements were performed by the mass spectrometry service of the LOC at the ETHZ on a Bruker Reflex MALDI-TOF using 2-[(2E)-3-(4tert-butylphenyl)-2-methylprop-2-enylidene]malononitrile as matrix $(20 \mathrm{kV})$. Infrared spectra were recorded on a Perkin Elmer Spectrum RX-I FT-IR spectrophotometer using $\mathrm{KBr}$ pellets or the Golden Gate technology. Analytical highperformance liquid chromatography (HLPC) was performed on a Merck Hitachi Chromatography System (Interface D-7000, UV detector L-7400, Pump L-7100, degaser). The flow rate was $1 \mathrm{ml} / \mathrm{min}$ and the detector wavelength was fixed at $\lambda=405$ nm. Column: LiChrospher® $100 \mathrm{RP}-18(5 \mu \mathrm{m})$ (LiChroCART® $(250 \mathrm{x} 4 \mathrm{~mm})$, (solvent A: $\mathrm{CH}_{3} \mathrm{CN}$, solvent B: $0.1 \%$ TFA in $\mathrm{H}_{2} \mathrm{O}$ ). All chromatograms were taken at ambient temperature.

\section{Susceptibility assays}

The MIC values were determined for the Saccharomyces cerevisiae wild type (BY4741, a derivative of S288C). ${ }^{1}$ The assays were inspired by the standard protocol approved by the National Committee of Clinical Laboratory Standards (NCCLS) but using YEPD liquid medium instead of the RPMI-1640 medium. ${ }^{2}$. The strains were cultivated overnight in 5 $\mathrm{mL}$ YEPD liquid medium at $30{ }^{\circ} \mathrm{C}$ with constant shaking. The saturated cultures were diluted to an $\mathrm{OD}_{600}$ of $0.1\left(3 \times 10^{7}\right.$. cells $/ \mathrm{mL})$. Using 24 wells plate, each well was prepared by adding $1 \%(12 \mu \mathrm{L})$ of DMSO solution of the tested compound

1. Brachmann, C. B.; Davies, A.; Cost, G. J.; Caputo, E.; Li, J.; Hieter, P.; Boeke, J. D.; Yeast 1998, $14,115$.

2. National Committee of Clinical Laboratory Standards. Reference Method for Broth Dilution Antifungal Susceptibility Testing of Yeast, M27-A2, Approved

Standard-Second Edition, Volume 22, Number 15, 1995. 
with $1 \%(12 \mu \mathrm{L})$ yeast cells solution and completed with YEPD $(1.176 \mathrm{~mL})$. The plates were sealed with Parafilm and then

incubated for 18 hours at $30^{\circ} \mathrm{C}$. The optical density was read at $600 \mathrm{~nm}$ using $1.5 \mathrm{~mL}$ cuvettes. The MIC value was defined as the drug concentration needed to inhibit growth at less than 5\% compared to a drug-free culture.

\section{$\underline{\text { Hemolytic assays }}^{3}$}

Human blood, anticoagulated with citrate or EDTA, was centrifuged $(2000 \mathrm{x} \mathrm{g})$ at $4{ }^{\circ} \mathrm{C}$ for 10 minutes. The pellets were washed three times with PBS buffer ( $\mathrm{pH} 7.2$ with $2 \mathrm{~g} / \mathrm{L}$ glucose) and then diluted to a concentration of $4 \%\left(4 \mathrm{x} 10^{8}\right.$. cells/mL). All experiments were done in triplicate and the total volume for the hemolysis tubes was $1.4 \mathrm{ml}$. The solutions were prepared by adding $1 \%(14 \mu \mathrm{L})$ of DMSO solution of the tested compound with $736 \mu \mathrm{L}$ of PBS buffer and completed with $750 \mu \mathrm{L}$ of $4 \%$ erythrocytes. After one hour incubation at $37{ }^{\circ} \mathrm{C}$, the samples were centrifuged $\left(1500 \mathrm{x}\right.$ g) at $4{ }^{\circ} \mathrm{C}$ for 5

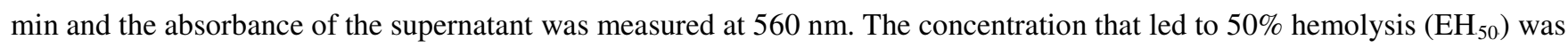
intrapolated graphically. The value for the $100 \%$ hemolysis was obtained by the treatment with $100 \mu \mathrm{M}$ of AmB.

\section{$\underline{\mathbf{K}^{+} \text {efflux assays: }}$}

The $\mathrm{K}^{+}$efflux measurements were made following a procedure previously described. ${ }^{4}$ The appropriate liposome suspensions were prepared using POPC, cholesterol and ergosterol. Then the liposomes were sized by extrusion through two $400 \mathrm{~nm}, 200 \mathrm{~nm}$, and finally $100 \mathrm{~nm}$ pore size membrane (ten times for each pore size). The resultant " $100 \mathrm{~nm}$ " unilamellar liposomes were dialyzed against $600 \mathrm{~mL}$ of $150 \mathrm{mM} \mathrm{NaCl}, 5 \mathrm{mM}$ HEPES (pH 7.4) buffer. After, the suspension was diluted with $150 \mathrm{mM} \mathrm{NaCl}, 5 \mathrm{mM}$ HEPES (pH 7.4) buffer to $1 \mathrm{mM}$ overall lipid concentration (phospholipids + sterols). For each efflux measurement $10 \mathrm{~mL}$ of this liposome suspension was placed in a small beaker. Potentiometric measurements were performed every second with a 16-channel electrode monitor in magnetically stirred solutions at ambient temperature. The reference electrode was a Metrohm double junction $\mathrm{Ag} / \mathrm{AgCl}$ reference electrode with $3 \mathrm{M} \mathrm{KCl}$ as reference electrolyte and 1 M LiOAc as bridge electrolyte. After recording the amphotericin-induced potassium efflux, liposomes were lysed by adding sodium cholate $(172 \mathrm{mg})$. The resulting reading (taken after $1 \mathrm{~h}$ ) was used to quantify the $100 \% \mathrm{~K}^{+}$release.

\footnotetext{
3. Kinsky, S. C.; Avruch, J.; Permutt, M.; Rogers, H. B. Biochem. Biophys. Res. Comm. 1962, 9, 503.

4. A. Zumbuehl, D. Jeannerat, S. E. Martin, M. Sohrmann, P. Stano, T. Vigassy, D. D. Clark, S. L. Hussey, M. Peter, B. R. Peterson, E. Pretsch, P. Walde, E. M. Carreira, Angew. Chem. Int. Ed. 2004, 43, 5181-5185.
} 


\section{$\underline{\text { Synthesis }}$}

25,26,27,28-Tetrakis[(aminohexanoylpiperazinyl-amphotericin B)carbonylmethoxy]-calix[4]arene (3):
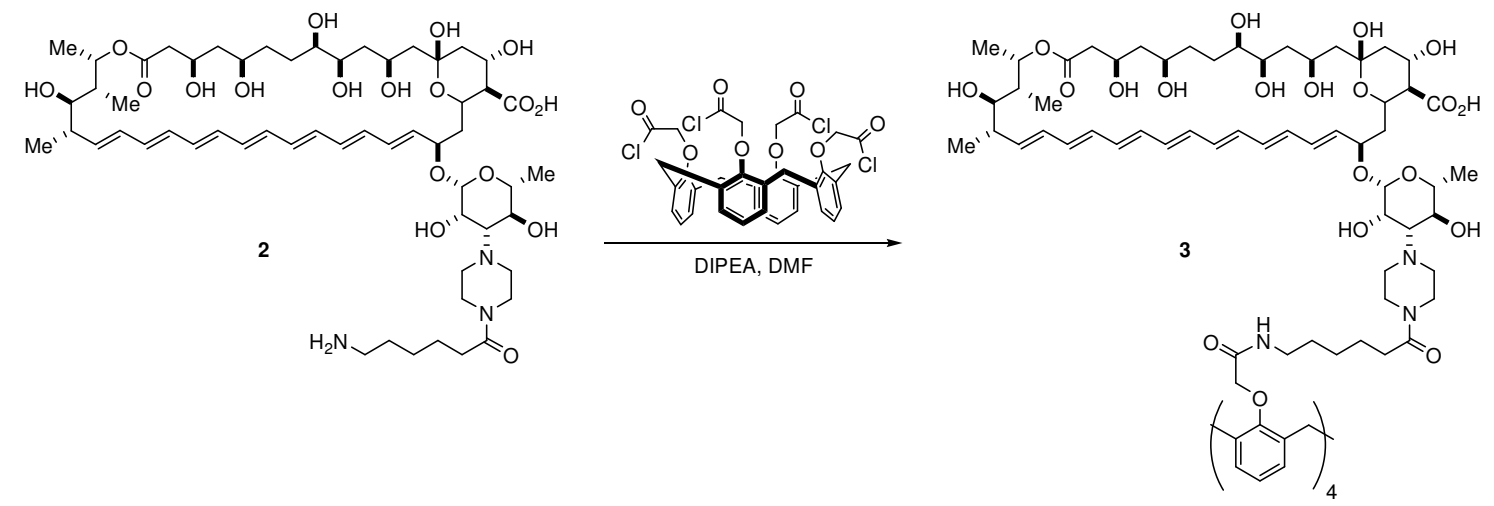

To a solution of 25,26,27,28-Tetrakis(chloroformylmethoxy)-calix[4]arene ${ }^{5}(22.0 \mathrm{mg}, \quad 0.030 \mathrm{mmol})$ and diisopropylethylamine $(0.100 \mathrm{~mL}, 1.00 \mathrm{mmol})$. in DMF $(3.00 \mathrm{~mL})$ was added aminohexanoyl piperazinyl amphotericin B $(2)^{4}$ (400 $\mathrm{mg}, 0.360 \mathrm{mmol}$ ). After 4 days at room temperature, the solution was concentrated and added dropwise to diethyl ether $(250 \mathrm{~mL})$. The yellow precipitate was filtered and purified by Sephadex LH-20 column (5\% Ultra2 in MeOH) providing the desired compound 3 as a yellow solid $(10.0 \mathrm{mg}, 7 \%) .{ }^{1} \mathrm{H}$ NMR (300 MHz, DMSO- $\left.d_{6}\right) \delta 7.27(\mathrm{~d}, J=8 \mathrm{~Hz}, 8 \mathrm{H})$, $6.76(\mathrm{t}, J=8 \mathrm{~Hz}, 4 \mathrm{H}), 6.45-5.78(\mathrm{~m}, 48 \mathrm{H}), 5.47-5.36(\mathrm{~m}, 8 \mathrm{H}), 5.23-5.18(\mathrm{~m}, 4 \mathrm{H}), 4.81-4.65(\mathrm{~m}, 12 \mathrm{H}), 4.44-3.81(\mathrm{~m}, 52 \mathrm{H})$, 3.37 (s (br), $O H), 3.11-3.07(\mathrm{~m}, 16 \mathrm{H}), 2.93-2.92(\mathrm{~m}, 8 \mathrm{H}), 2.40-2.28(\mathrm{~m}, 32 \mathrm{H}), 2.16(\mathrm{~d}, J=6 \mathrm{~Hz}, 4 \mathrm{H}), 1.60-1.21(\mathrm{~m}, 80 \mathrm{H})$, $1.17(\mathrm{~d}, J=6 \mathrm{~Hz}, 12 \mathrm{H}), 1.11(\mathrm{~d}, J=6 \mathrm{~Hz}, 12 \mathrm{H}), 1.04(\mathrm{~d}, J=6 \mathrm{~Hz}, 12 \mathrm{H}), 0.91(\mathrm{~d}, J=7 \mathrm{~Hz}, 12 \mathrm{H})$. MALDI-TOF $(\mathrm{m} / \mathrm{z}):[\mathrm{M}+$ $\mathrm{Na}]^{+}$calcd for $\mathrm{C}_{264} \mathrm{H}_{388} \mathrm{~N}_{12} \mathrm{NaO}_{80}$ : 5028.6481; found: 5026.5 (broad). ${ }^{6}$ Anal. RP-HPLC: $R \mathrm{t}=22.70$ min $(\mathrm{C} 18,90 \% \mathrm{~A}$ and $10 \% \mathrm{~B}$ for $30 \mathrm{~min})$.

5,11,17,23-Tetra-tert-butyl-25,26,27,28-tetrakis[(aminohexanoylpiperazinyl-amphotericin B)carbonylmethoxy]-

calix[4]arene (4):

5. Casnati, A., Ting, Y., Berti, D., Fabbi, M., Pochini, A., Ungaro, R., Sciotto, D., Lombardo, G. G. Tetrahedron 1993, 49, 9815-9822.

6. Some high molecular weight conjugates of AmB give poor results using MALDI-TOF techniques; see Sedlak, M., Buchta, V., Kubicova, L., Simunek, P., Holcapek, M., Kasparova, P. Bioorg. Med. Chem. Lett. 2001, 11, 2833-2835. 

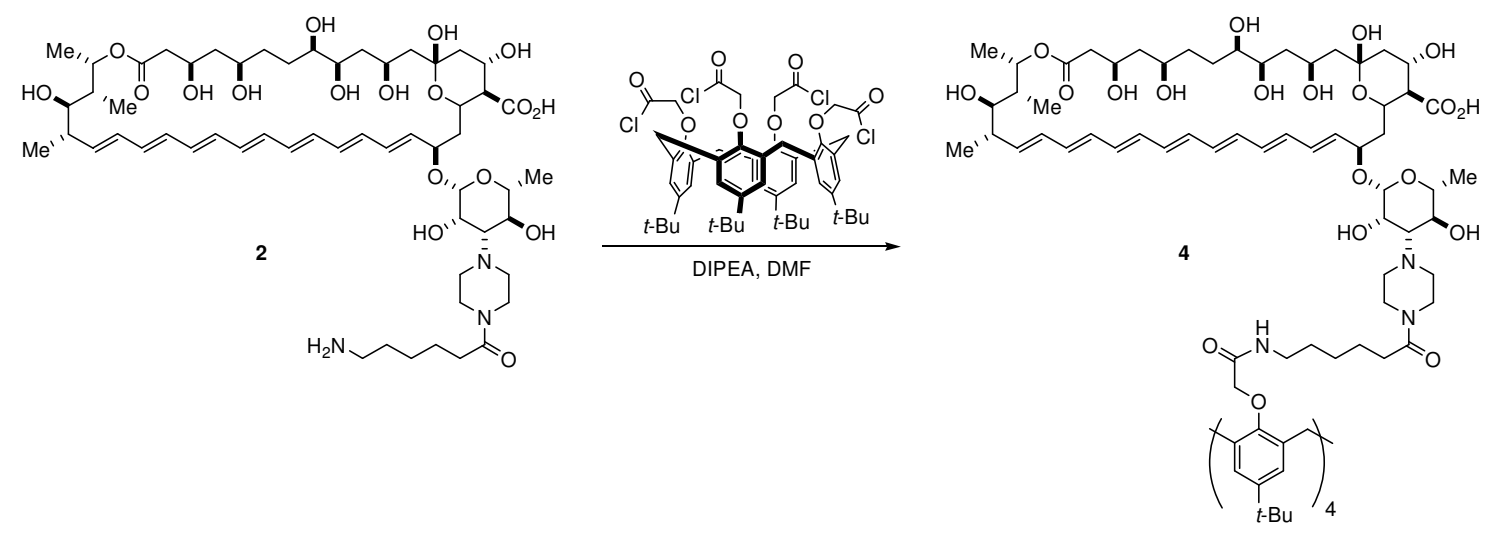

To a solution of 5,11,17,23-Tetra-tert-butyl-25,26,27,28-tetrakis(chloroformylmethoxy)-calix[4]arene ${ }^{7}$ (27.0 mg, $0.030 \mathrm{mmol})$ and diisopropylethylamine $(0.100 \mathrm{~mL}, 1.00 \mathrm{mmol})$ in $\mathrm{DMF}(3.00 \mathrm{~mL})$ was added aminohexanoyl piperazinyl amphotericin B $(2)^{4}(400 \mathrm{mg}, 0.360 \mathrm{mmol})$. After 4 days at room temperature, the solution was concentrated and added dropwise to diethyl ether $(250 \mathrm{~mL})$. The yellow precipitate was filtered and purified by Sephadex LH-20 column (5\% Ultra2 in $\mathrm{MeOH}$ ) providing the desired compound 4 as a yellow solid $(26.0 \mathrm{mg}, 17 \%) .{ }^{1} \mathrm{H}$ NMR $\left(300 \mathrm{MHz}, \mathrm{DMSO}-d_{6}\right) \delta 7.27(\mathrm{~s}$, 8H), 6.50-5.95 (m, 48H), 5.84-5.81 (m, 4H), 5.47-5.37 (m, 4H), 5.23-5.18 (m, 4H), 4.81-4.65 (m, 12H), 4.45-3.82 (m, 52H), 3.37 (s (br), $O H), 3.11-3.05(\mathrm{~m}, 16 \mathrm{H}), 2.75-2.72(\mathrm{~m}, 8 \mathrm{H}), 2.28-2.14(\mathrm{~m}, 8 \mathrm{H}), 2.17(\mathrm{~d}, J=6 \mathrm{~Hz}, 4 \mathrm{H}), 1.70-1.23(\mathrm{~m}, 84 \mathrm{H})$, $1.17(\mathrm{~s}, 36 \mathrm{H}), 1.11(\mathrm{~d}, J=6 \mathrm{~Hz}, 12 \mathrm{H}), 1.04(\mathrm{~d}, J=7 \mathrm{~Hz}, 12 \mathrm{H}), 0.91(\mathrm{~d}, J=7 \mathrm{~Hz}, 12 \mathrm{H})$. MALDI-TOF $(\mathrm{m} / \mathrm{z}):[\mathrm{M}+\mathrm{H}]^{+}$calcd for $\mathrm{C}_{280} \mathrm{H}_{420} \mathrm{~N}_{12} \mathrm{O}_{80}$ : 5230.9166; found: 5212.7 (broad). ${ }^{6}$ Anal. RP-HPLC: $R \mathrm{t}=21.85 \min (\mathrm{C} 18,90 \%$ A and $10 \%$ B for 30 $\min )$.

7. Arnaud-Neu, F., Barrett, G., Crernin, S., Deasy, M., Ferguson, G., Harris, S. J., Lough, A. J., Guerra, L., McKervey, M. A., Schwing-Weilla, M. J., Schwinte, P. (1992) Selective alkali-metal cation complexation by chemically modified calixarenes. Part 4 . Effect of substituent variation on the Na+/K+ selectivity in the ester series and X-Ray crystal structure of the trifluoroethyl ester. J. Chem. Soc. Perkin Trans. 2, 1119-1125. 


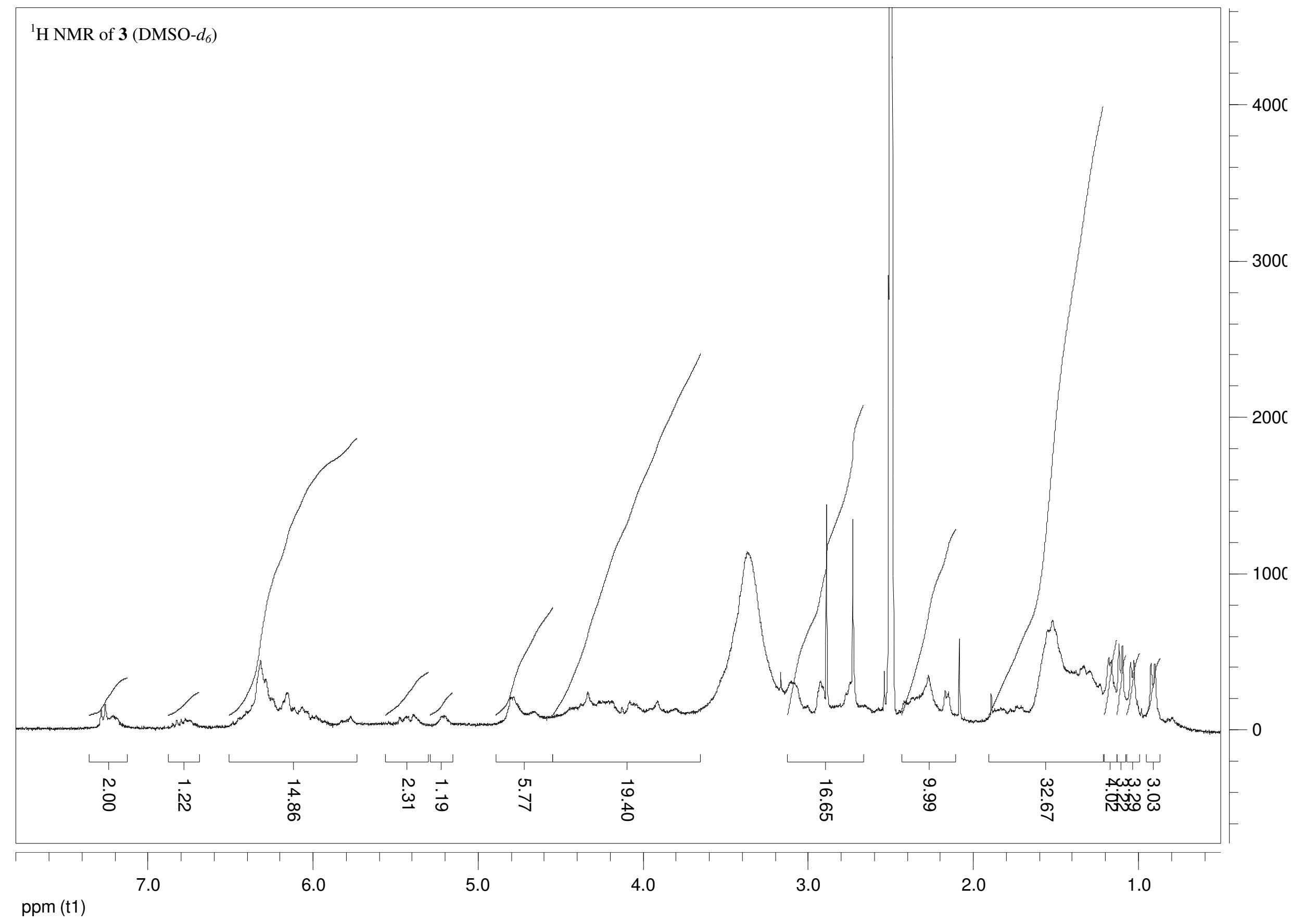




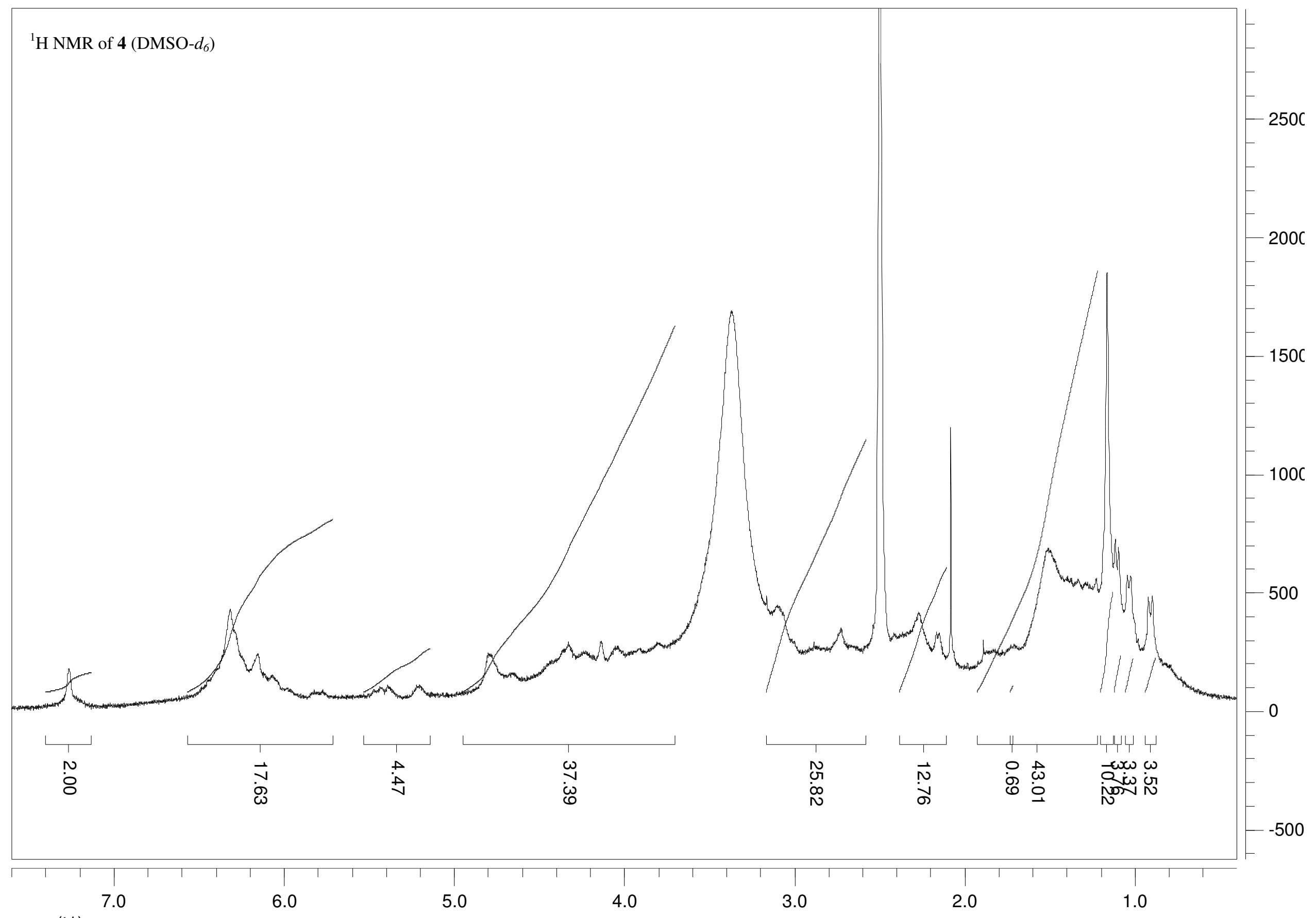

ppm (t1) 


\section{HPLC of Conjugate 3}

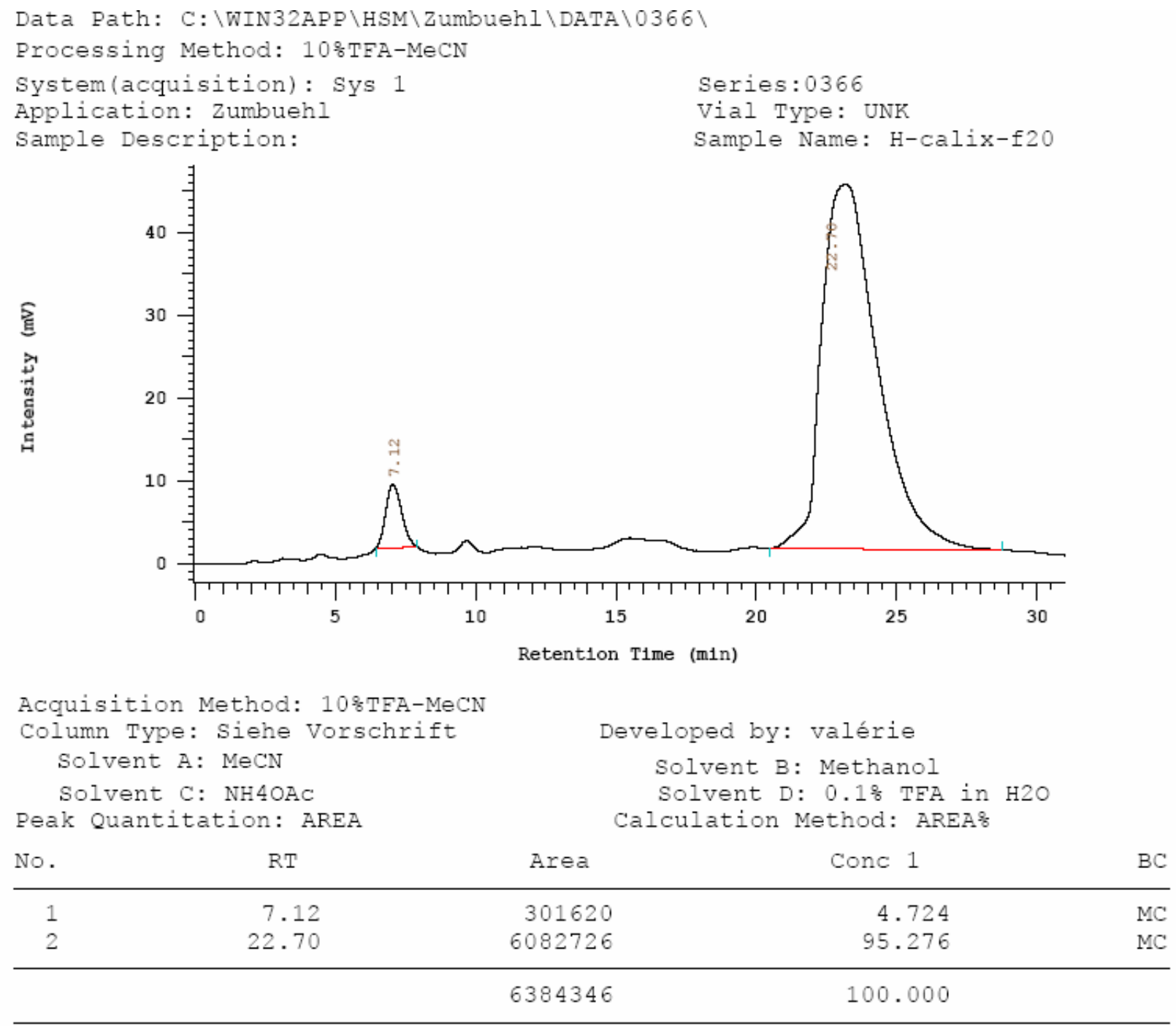

Peak rejection level: 0 


\section{HPLC of Conjugate 4}
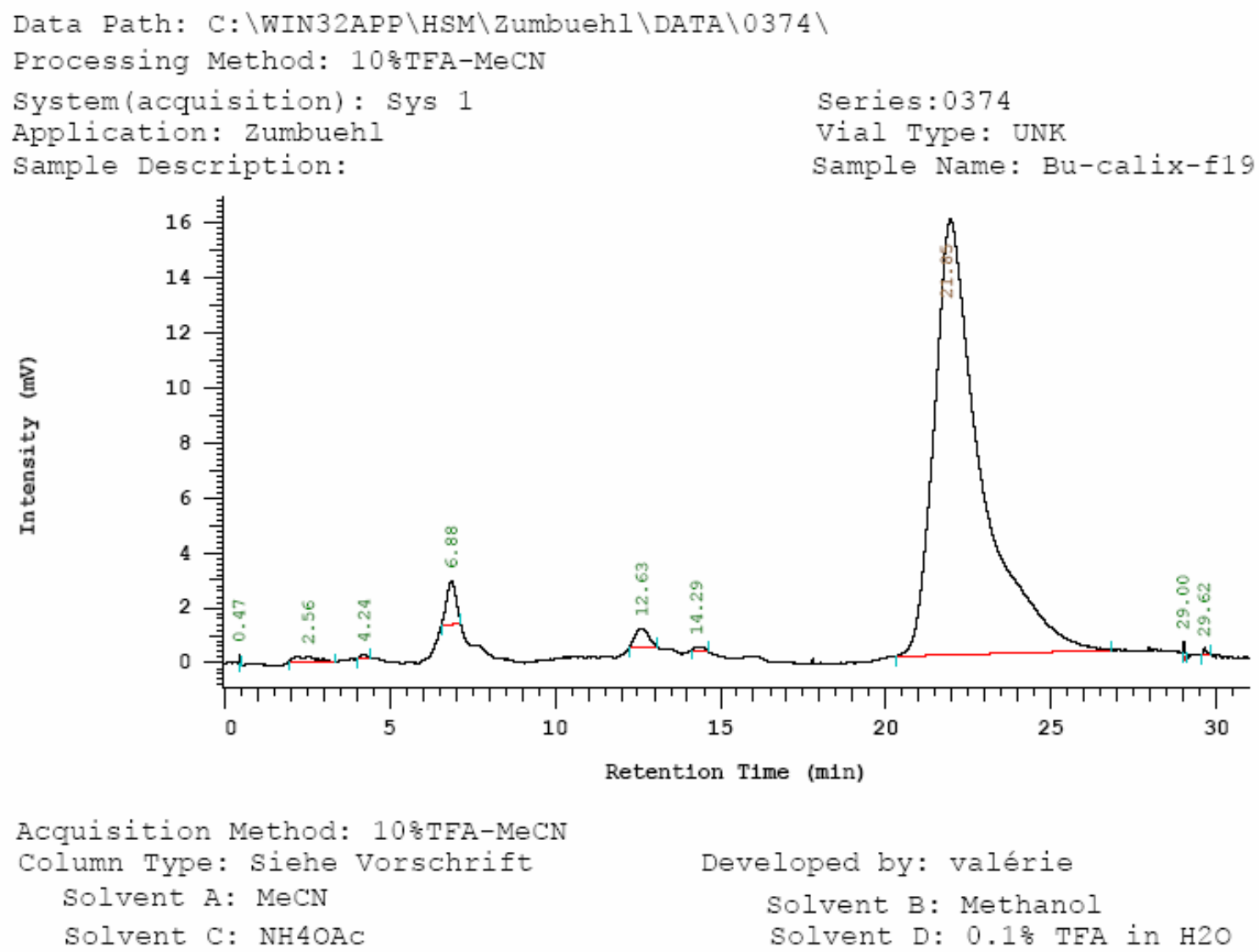

\begin{tabular}{|c|c|c|c|c|}
\hline No. & RT & Area & Conc 1 & $\mathrm{BC}$ \\
\hline 1 & 0.47 & 330 & 0.020 & $\mathrm{BB}$ \\
\hline 2 & 2.56 & 9259 & 0.574 & $\mathrm{BB}$ \\
\hline 3 & 4.24 & 2192 & 0.136 & $\mathrm{BB}$ \\
\hline 4 & 6.88 & 29815 & 1.848 & $\mathrm{BB}$ \\
\hline 5 & 12.63 & 19354 & 1.200 & $\mathrm{BB}$ \\
\hline 6 & 14.29 & 3119 & 0.193 & $\mathrm{BB}$ \\
\hline 7 & 21.85 & 1546156 & 95.828 & $\mathrm{MC}$ \\
\hline 8 & 29.00 & 2240 & 0.139 & $\mathrm{BB}$ \\
\hline 9 & 29.62 & 993 & 0.062 & $\mathrm{BB}$ \\
\hline
\end{tabular}

Peak rejection level: 0 


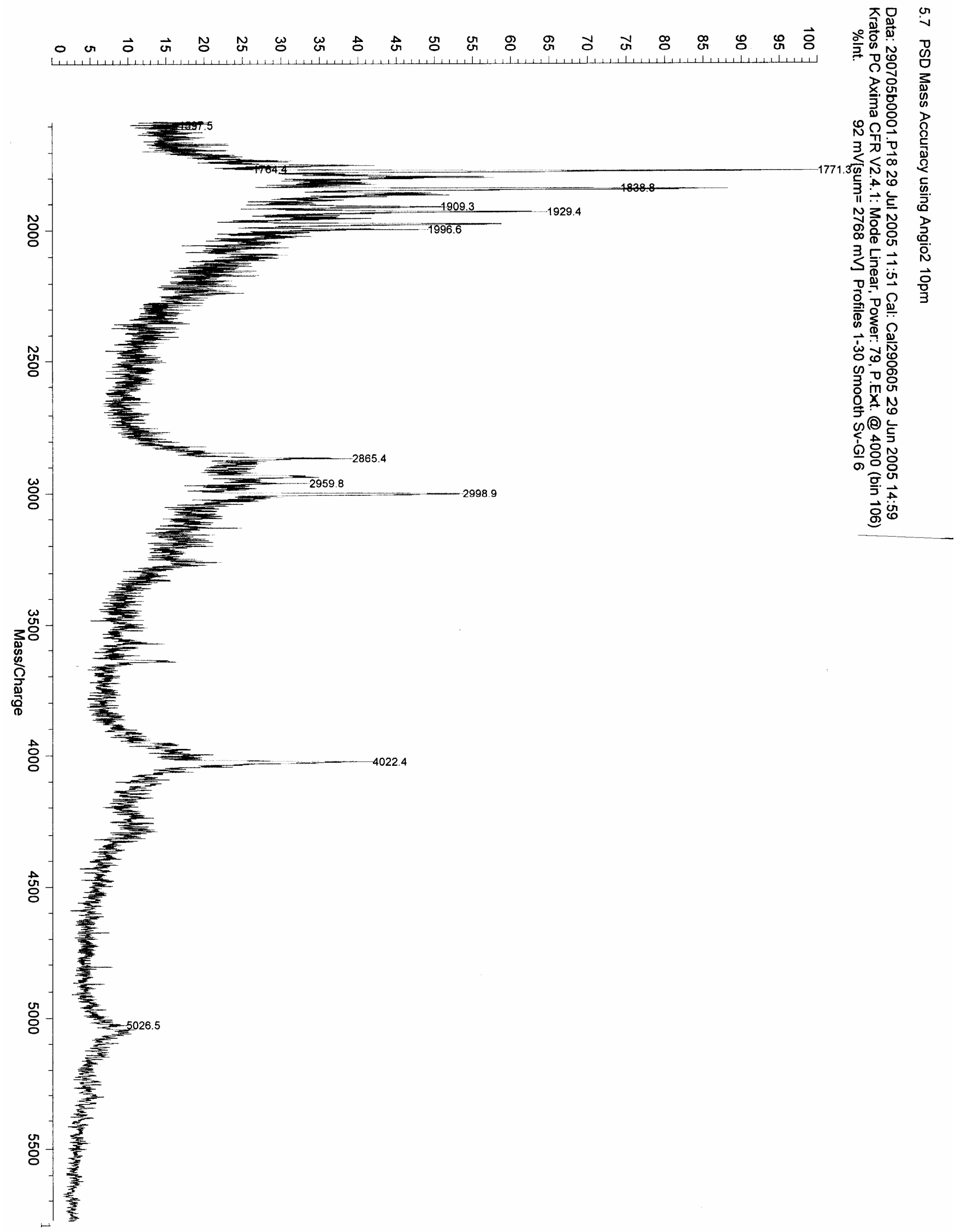




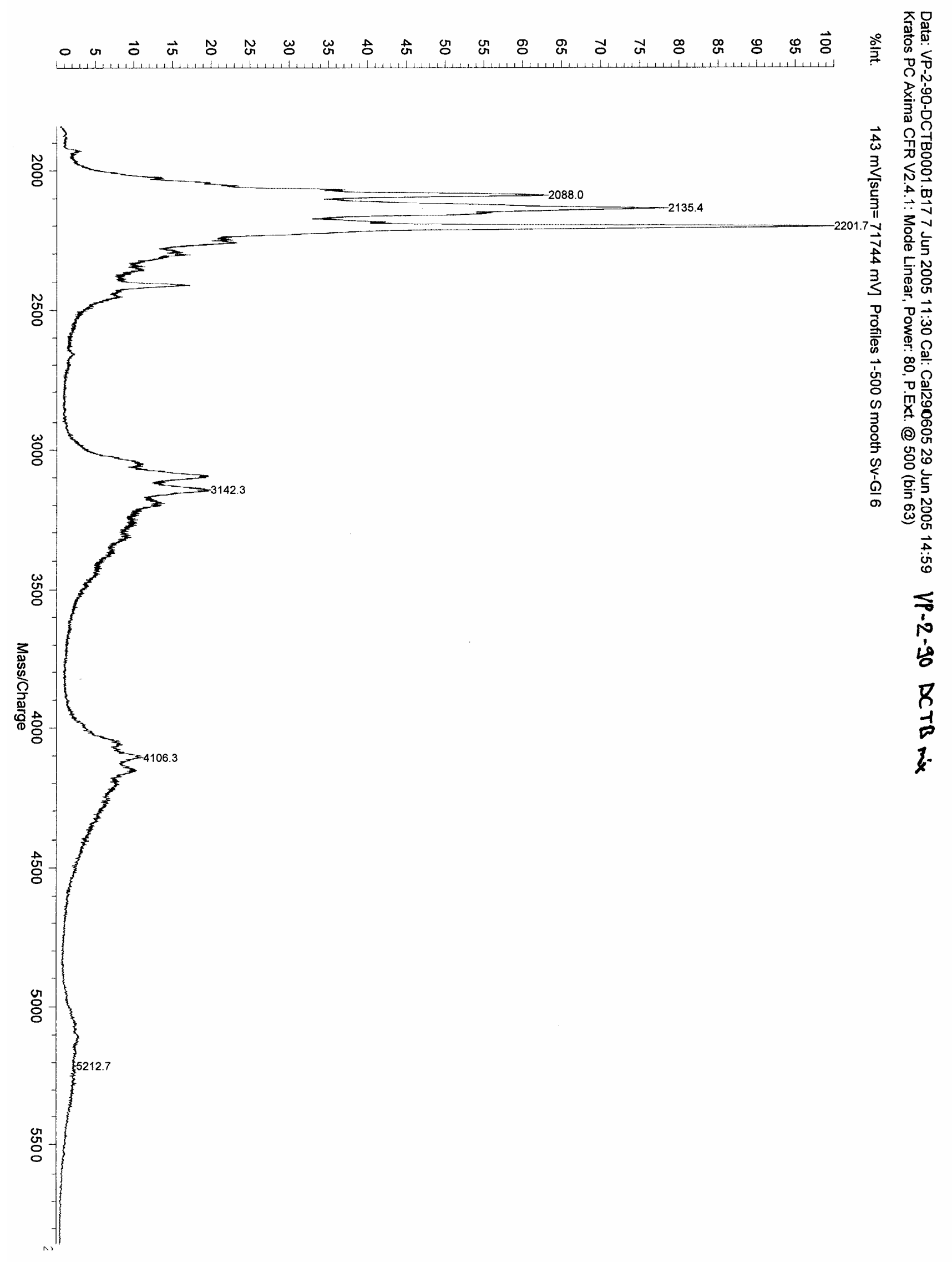

